Research Article

\title{
Assessment for Agronomic and Grain Qualitative Attributes of Wheat Cultivars under Agro-ecological Conditions of Faisalabad
}

\author{
Muhammad Dawood ${ }^{1,2}$, Naeem Sarwar ${ }^{2}$, Muhammad Umer Chattha ${ }^{1}$, Imran Khan ${ }^{1}$, Muhammad Bilal \\ Chattha $^{3 *}$, Faiz Hussain ${ }^{4}$, Muhammad Mahmood Iqbal', Muhammad Akram ${ }^{4}$, Hammad Husnain ${ }^{5}$, \\ Muhammad Shahid ${ }^{5}$, Mussarrat Hussain ${ }^{6}$ and Muhammad Umair Hassan ${ }^{1}$
}

${ }^{1}$ Department of Agronomy, University of Agriculture, Faisalabad, 38040, Pakistan; ${ }^{2}$ Department of Agronomy, Bahauddin Zakariya University Multan, Multan, Pakistan; ${ }^{3}$ Institute of Agricultural Sciences, University of the Punjab, Lahore, Pakistan; ${ }^{4}$ Directorate of Agronomy, Ayub Agricultural Research Institute, Faisalabad, Pakistan; ${ }^{5}$ Cotton Research Institute Multan, $\mathrm{Pa}$ kistan; ${ }^{6}$ Entomological Research Station, Multan, Pakistan.

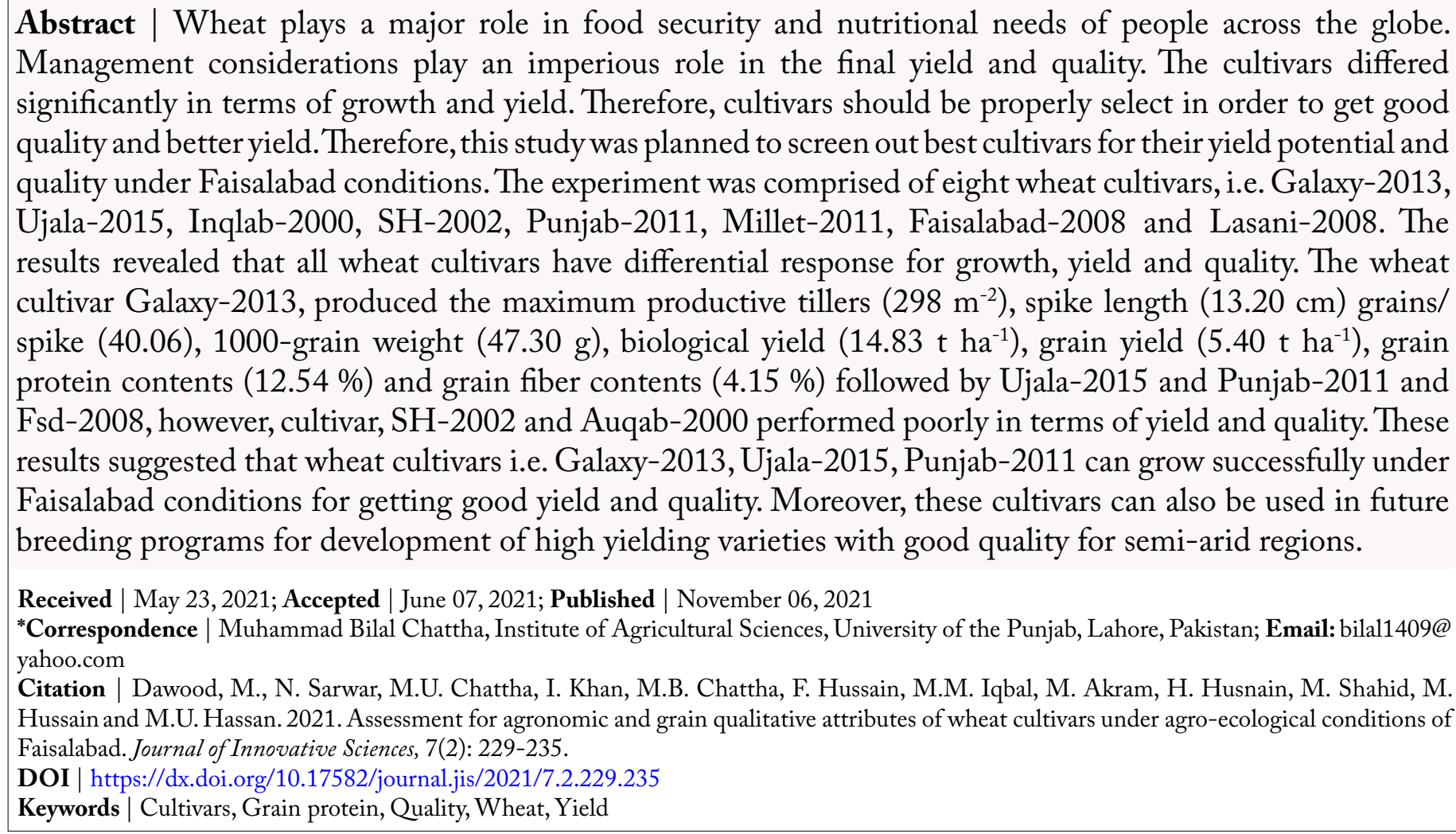

\section{Introduction}

W Theat is an imperative cereal crop globally and the staple food of many nations. It has major role in providing the daily calories, proteins, carbohydrates and micronutrients globally (Chattha et al., 2017a; Hassan et al., 2019a, 2021). In Pakistan, wheat also occupies a major position in the context of area under cultivation and provision of calories and carbohydrates (Iqbal et al., 2002). Wheat has a contribution of $1.7 \%$ in gross domestic production and $8.7 \%$ in value addition in agriculture sector of Pakistan (GoP, 2020). The demand of wheat in Pakistan is increasing rapidly due to blooming population however wheat production is continuously decreasing owing to weeds infestation, late cotton harvesting, 
poor nutrient management and un-availability of high yield cultivars (Chattha et al., 2017b; Zain et al., 2017b; Muhsin et al., 2021). Likewise, global food production is also continuously decreasing owing to different biotic and abiotic stress (Hassan et al., 2019b, 2020a, b). Moreover, urbanization also reduced the area under wheat cultivation therefore, there is dire need to increases the per unit yield of wheat crop in order to fulfill human needs.

Management practices play a crucial role in the final outcome of crops. Among the management practices, selection of suitable cultivar plays a crucial role in grain and biomass productivity (Iqbal et al., 2015; Hassan et al., 2018, 2019c, 2020c). The selection and development of high yield potential cultivars is the prime objective of breeding programs globally. Thus, it is imperative to identify the genotypes with desired traits in order to develop the new genotypes (Mary and Gopalan, 2006). In addition, the development of new genotypes required the knowledge of differences present among the cultivars for yield and yield attributes (Jamal et al., 2009). The population of world including Pakistan is increasing rapidly, therefore, in order to fulfill the requirements of ever blooming population there is dire need to develop the high yielding genotypes or to increase the production per unit basis. Therefore, the screening of wheat cultivars for agronomic as well as yield and yield attributes would be helpful for the development of high yielding cultivars with good resistance against the insect pest and diseases (Shafi et al., 2013).

Grain yield is the interplay of environmental conditions, management practices and genetic characters of a variety. Therefore, grain yield of wheat crop mostly assessed on performance of yield attributes (Razzaq et al., 2013). The variations present among the cultivars in the context of yield components can be helpful for the development of high yielding new genotypes with good quality (Kahrizi et al., 2010). The economic yield of wheat can be improved by choosing the cultivars having more spikelet's, grain weight, grains count per spike (Inamullah et al., 2006), leaf area, tillers and spike length (Saleem et al., 2006). Significant variations can be found among the cultivars in the context of growth, yield and yield components and grain quality (Iqbal et al., 2015). Wheat cultivars can vary in terms of tillers, spike lengths, grains/spike and 1000 grain weight. Therefore, identification of genotypes with better yield traits is helpful in development of new cultivars with high yield and quality (Nasim et al., 2012). Management consideration and prevailed environmental conditions substantially influenced the yield potential of genotypes (Delibaltova and Kirchev, 2010). Each variety has specific genotypic ability to perform in different environmental conditions. This ability is usually plays a substantial role in the performance of a variety at farmers field over wide range of agro-ecological conditions (Bonjean and Angus, 2001). Therefore, there is dire need to develop the varieties that should perform better over the wide range of environmental conditions (Ofversten et al., 2002). Therefore, this study was conducted to screen out best cultivars for their yield potential and quality under Faisalabad conditions.

\section{Materials and methods}

\subsection{Experimental site}

The proposed investigation was carried out at the Post Graduate Agriculture, Research Station (PARS), University of Agriculture, Faisalabad during 20152016. Prior to sowing soil samples from different locations of experimental field were collected and subjected to determine different soil properties. The soil was sandy loam with $\mathrm{pH} 7.8$, available nitrogen $0.014 \%$, phosphorus and potassium 16 and $172 \mathrm{mg}$ $\mathrm{kg}^{-1}$. The study site has semi-arid climate with hot summer and dry and humid winter further climatic conditions during growing period are given in Table 1.

Table 1: Prevailing weather conditions during wheat growing period.

\begin{tabular}{llll}
\hline Months & $\begin{array}{l}\text { Monthly average } \\
\text { temperature }\left({ }^{\circ} \mathbf{C}\right)\end{array}$ & $\begin{array}{l}\text { Relative } \mathbf{H u}- \\
\text { midity }(\mathbf{\%})\end{array}$ & $\begin{array}{l}\text { Rain fall } \\
(\mathbf{m m})\end{array}$ \\
\hline Nov-2015 & 19.6 & 61.5 & 8.8 \\
Dec-2015 & 14.5 & 62.6 & 0 \\
Jan-2016 & 12.5 & 74.4 & 13.1 \\
Feb-2016 & 16.3 & 58.1 & 7.8 \\
Mar-2016 & 21.1 & 59.7 & 66.7 \\
Apr-2016 & 27.2 & 34.2 & 5.6 \\
\hline
\end{tabular}

\subsection{Experimental details}

The experiment was laid out in randomized complete block design (RCBD) with three replications. The experiment was consisting of different wheat cultivars; Ujala-2015, Galaxy-2013, Millet-2011, Punjab-2011, Lasani-2008, Faisalabad-2008, SH2002 and Auqab-2000. 
2.3 Crop husbandry

The seed bed for sowing of wheat cultivars was prepared by cultivation twice followed by planking. The crop was sown on November 24, 2015 using a seed rate of $125 \mathrm{~kg} / \mathrm{ha}^{-1}$ in $23 \mathrm{~cm}$ spaced rows. Seed was sown by using hand drill. The NPK fertilizers were used at the rate of 105:80:55 kg ha-1. Complete dose of $\mathrm{P}$, and $\mathrm{K}$ and half dose of $\mathrm{N}$ were applied at sowing. Moreover, the rest of $\mathrm{N}$ was applied with first irrigation. The sources of N, P, K were urea ( $46 \%$ $\mathrm{N})$, single super phosphate (21\%) and sulphate of potash $\left(50 \% \mathrm{~K}_{2} \mathrm{O}\right)$. During the growing period four irrigations were applied. In addition, all the agronomic practices were kept normal for maintenance proper growth and development of crop.

\subsection{Observations}

Twenty plants from each plot were randomly selected and plant height was measured with measuring tape and later on averaged. A unit area from each plot was selected and number of tillers was calculated. Twenty spikes were selected randomly from each plot and their length was measured and spikelet's and grains/ spike were counted. A sub sample of seeds were taken from the seed lot and weighed to measure the 1000 grain weight. The whole plots were harvested and weighed to determine biological and later on threshed to determine grain yield. The grain samples were dried in oven and later on grinded with the help of grinder. The grain protein and fiber contents content were determined by the standard procedures of AOAC (1990), and (Iqbal et al., 2015) whereas grain $\mathrm{N}$ and $\mathrm{P}$ measured by standard procedure of (Olsen et al., 1954) and (Chapman and Parker, 1961). Similarly, grain K content was measured by using flame photometer from the standard curve.

\subsection{Statistical analysis}

The collected data on the various traits was analyzed by Fisher's analysis of variance technique and difference amongst mean values was compared using HSD test at 5\% probability level (Steel et al., 1997).

\section{Results and Discussion}

The results indicated different cultivars had significant impact on the yield and yield traits. The maximum plant height $(111 \mathrm{~cm})$ was noticed in Punjab-2011 that was comparable with millet-2011 and Fsd-2008 and minimum plant height (92.33 $\mathrm{cm})$ was recorded in SH-2002. Similarly, maximum productive tillers (298) was recorded in Galaxy-2013 that was same with Fsd-2008 and Ujala-2015 and minimum productive tillers (250) were noted in SH-2002 (Table 2). The cultivars had substantiated difference for the plant height and tillers and this different could be due to difference in their genetic characteristics (Hussain et al., 2006; Chattha et al., 2017c; Ilyas et al., 2020). Similarly, maximum spike length $(13.20 \mathrm{~cm})$ was noticed in Galaxy-2013, after that Ujala $(12.63 \mathrm{~cm})$ and minimum spike length $(9.26 \mathrm{~cm})$ was recorded in SH-2002 (Table 2). The difference among the cultivars for spike length can be to prevailing weather conditions, soil nutrient status and in combination with genetic inheritance of cultivars (Naveed et al., 2014). Cultivars showed significant differences for spikelet, and grains/spike (Table 2). The maximum spikelets (13.66) were recorded in Ujala-2015 after that Millet-2011 and Punjab-2011, whereas lowest spikelets were noticed in SH-2002 (Table 2). Similarly, maximum grains/ spike (44.23) was recorded in Millet-2011 after that Galaxy-2013 and minimum grains/spike (31.16) was recorded Auqab-2000 (Table 2). The difference amid the cultivars for the spikelet and grains/spike can be difference in biomass production and leaf area, as varieties having more leaf area produced more assimilates and thus have the higher spikes and grains/ spike (Mushtaq et al., 2011; Naveed et al., 2014; Ayaz, 2016). A significant difference among the cultivars for the 1000 grain weight (GW) was noticed (Table 3). The maximum $1000 \mathrm{GW}$ (47.30 g) was recorded in Galaxy-2011 after that Ujala-2015 (45.30 g) and minimum $1000 \mathrm{GW}$ (34.20 g) was recorded in SH2002 (Table 3). The difference among cultivars for $1000 \mathrm{GW}$ can be due difference in their genetic traits as few varieties produced bold seeds owing to higher leaf area and assimilates production compared to other varieties. These results are in confirmation with Kiliç and Gürsoy (2010) they also noticed significant differences among cultivars for $100 \mathrm{GW}$.

Similarly, the maximum biological yield (14.83 t $\mathrm{ha}^{-1}$ ) and grain yield (5.40 $\left.\mathrm{t} \mathrm{ha}^{-1}\right)$ was recorded in Galaxy-2013 followed by Fsd-2008 and minimum biological (11.23 $\left.\mathrm{t} \mathrm{ha}^{-1}\right)$ and grain yield (3.43 $\mathrm{t} \mathrm{ha}$ $\left.{ }^{1}\right)$ was recorded in SH-2002 (Table 3). Grain yield in wheat crops is interplay of individual yield traits, genetic potential, environmental conditions and inputs to be used for growing. The maximum grain yield was recorded in Galaxy-2013 owing to higher assimilates production, higher leaf area, and individual yield 
Table 2: Effect of different cultivars on yield traits of wheat crop.

\begin{tabular}{llllll}
\hline Varieties & Plant height $\mathbf{( c m})$ & Productive tillers $\left.\mathbf{( m}^{2}\right)$ & Spike length $\mathbf{( c m})$ & Spikelet's/ spike & Grains/spike \\
\hline Ujala-2015 & $108.00 \mathrm{~A}$ & $288.00 \mathrm{AB}$ & $12.63 \mathrm{AB}$ & $13.66 \mathrm{~A}$ & $39.20 \mathrm{AB}$ \\
Galaxy-2013 & $101.00 \mathrm{AB}$ & $298.33 \mathrm{~A}$ & $13.20 \mathrm{~A}$ & $12.20 \mathrm{BC}$ & $40.06 \mathrm{AB}$ \\
Millet-2011 & $106.67 \mathrm{~A}$ & $277.67 \mathrm{ABC}$ & $11.91 \mathrm{ABC}$ & $12.63 \mathrm{AB}$ & $44.23 \mathrm{~A}$ \\
Punjab-2011 & $111.00 \mathrm{~A}$ & $287.67 \mathrm{AB}$ & $12.56 \mathrm{AB}$ & $12.76 \mathrm{AB}$ & $38.00 \mathrm{ABC}$ \\
Lasani-2008 & $92.67 \mathrm{~B}$ & $263.33 \mathrm{BC}$ & $10.04 \mathrm{CD}$ & $10.43 \mathrm{DE}$ & $34.86 \mathrm{BC}$ \\
Fsd-2008 & $102.67 \mathrm{AB}$ & $274.33 \mathrm{ABC}$ & $11.63 \mathrm{~A}-\mathrm{D}$ & $12.50 \mathrm{~B}$ & $36.96 \mathrm{BC}$ \\
SH-2002 & $92.33 \mathrm{~B}$ & $250.00 \mathrm{C}$ & $9.26 \mathrm{D}$ & $9.56 \mathrm{E}$ & $34.40 \mathrm{BC}$ \\
Auqab-2000 & $94.33 \mathrm{~B}$ & $272.00 \mathrm{ABC}$ & $10.73 \mathrm{BCD}$ & $11.13 \mathrm{CD}$ & $31.16 \mathrm{C}$ \\
HSD $\leq 0.05 \mathrm{P}$ & 11.70 & 31.80 & 2.44 & 1.14 & 7.26 \\
\hline
\end{tabular}

Means with different letters differed at $0.05 \mathrm{P}$ level.

components including the tillers, $1000 \mathrm{GW}$, spikes and grains/spike. Similarly, maximum biological yield was also noticed in Galaxy which can be due to higher biomass and tillers production which is same with findings of and Malik et al. (2009) and Bhutta et al. (2019) they also noticed significant difference among cultivars for grain and biological yield. Moreover, maximum harvest index ( $\mathrm{HI})$ was also recorded in Galaxy-2013 owing to higher grain and biological yield compared to other cultivars (Table 3 ).

Table 3: Effect of different cultivars on yield and yield traits of wheat crop.

\begin{tabular}{lllll}
\hline Varieties & $\begin{array}{l}\text { 1000 grain } \\
\text { weight }\end{array}$ & $\begin{array}{l}\text { Biological } \\
\text { yield } \mathbf{( t} \\
\left.\mathbf{h a}^{-1}\right)\end{array}$ & $\begin{array}{l}\text { Grain } \\
\text { yield }(\mathbf{t} \\
\left.\mathbf{h a}^{-\mathbf{1}}\right)\end{array}$ & $\begin{array}{l}\text { Harvest } \\
\text { index }\end{array}$ \\
\hline Ujala-2015 & $45.30 \mathrm{~B}$ & $14.16 \mathrm{~B}$ & $4.73 \mathrm{~B}$ & $33.41 \mathrm{BC}$ \\
Galaxy-2013 & $47.30 \mathrm{~A}$ & $14.83 \mathrm{~A}$ & $5.40 \mathrm{~A}$ & $36.40 \mathrm{~A}$ \\
Millet-2011 & $41.33 \mathrm{C}$ & $12.80 \mathrm{C}$ & $4.40 \mathrm{CD}$ & $34.37 \mathrm{AB}$ \\
Punjab-2011 & $42.43 \mathrm{C}$ & $13.93 \mathrm{~B}$ & $4.56 \mathrm{BC}$ & $32.78 \mathrm{BCD}$ \\
Lasani-2008 & $35.56 \mathrm{E}$ & $11.50 \mathrm{DE}$ & $3.50 \mathrm{E}$ & $30.43 \mathrm{E}$ \\
Fsd-2008 & $41.10 \mathrm{C}$ & $13.73 \mathrm{~B}$ & $4.16 \mathrm{D}$ & $30.33 \mathrm{E}$ \\
SH-2002 & $34.20 \mathrm{~F}$ & $11.23 \mathrm{E}$ & $3.43 \mathrm{E}$ & $30.56 \mathrm{DE}$ \\
Auqab-2000 & $39.03 \mathrm{D}$ & $11.83 \mathrm{D}$ & $3.71 \mathrm{E}$ & $31.40 \mathrm{CDE}$ \\
HSD $0.05 \mathrm{P}$ & 1.36 & 0.48 & 0.29 & 2.24 \\
\hline
\end{tabular}

Means with different letters differed at $0.05 \mathrm{P}$ level.

The cultivars also had substantiated difference for tested qualities traits except grain $\mathrm{P}$ contents (Table 4). The maximum fiber content $(4.86 \%)$ was recorded in Fsd-2008 after that Lasani-2008 and minimum grain fiber contents (4.15\%) was recorded in Galaxy-2013 (Table 4). Likewise, maximum grain protein contents (12.54\%) were recorded in Galaxy-2013, that was same with Ujala-2015, Punjab-2011 and Lasanin-2008 and minimum protein contents $(9.43 \%)$ were recorded in Sh-2002 (Table 4).
Moreover, maximum grain $\mathrm{N}$ content $(1.85 \%)$ were recorded in SH-2002, after that Punjab-2011 and minimum grain $\mathrm{N}$ content $(1.55 \%)$ were recorded in Ujala-2015 (Table 4). The maximum grain $\mathrm{K}$ contents $(0.75 \%)$ were recorded in Lasani-2008 that was same with Ujala-2015 and minimum grain $\mathrm{K}(0.62 \%)$ were recorded in Auqab-2000 (Table 4). The cultivars had substantiated differences for the grain qualitative traits. The difference amid the cultivars for the qualitative traits can be due to difference in the genetic traits. The Galaxy-2013 had maximum N and K which indicate that this cultivar had better nutrient uptake particularly $\mathrm{N}$ and $\mathrm{K}$ which improved the final grain quality in terms of better protein contents compared to other cultivars (Table 4 ). The currents outcomes are same with results of Migliorini et al. (2016) and Ali et al. (2021) they also noticed significant differences among cultivars for the qualitative traits.

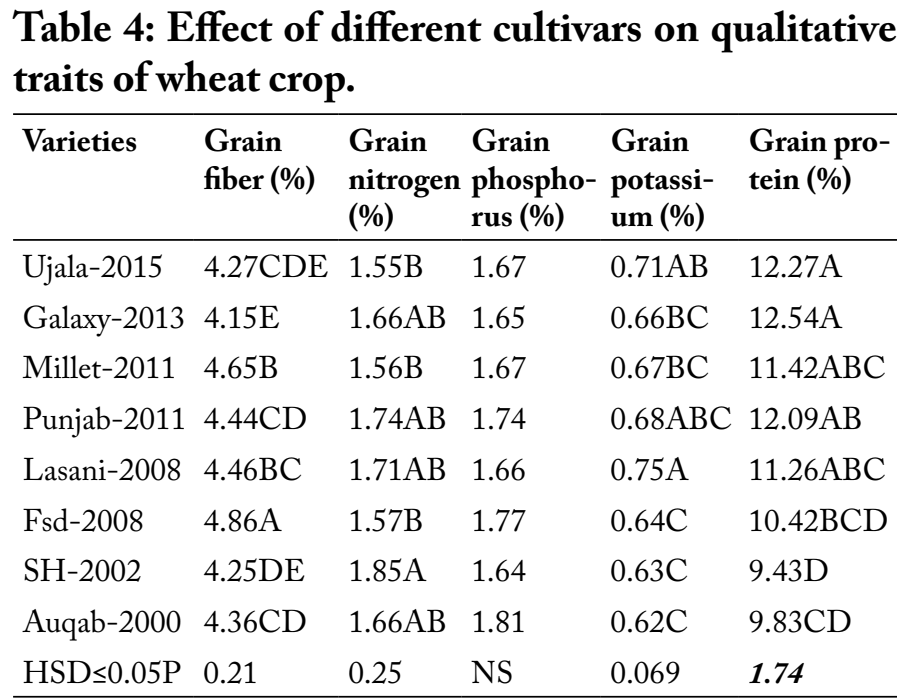

Means with different letters differed at $0.05 \mathrm{P}$ level.

\section{Conclusions and Recommendations}

The present study revealed that Galaxy-2013, 
Ujala-2015, Punjab-2011and Fsd-2008 performed appreciable well with maximum yield and quality compared to other tested cultivars. Therefore, this group of cultivars is of practical use for wheat breeders and they can be used in future breeder programs to develop the cultivars with higher yield potential and better quality.

\section{Novelty Statement}

This study tested the potential of different wheat cultivars for yield and quality traits under Faisalabad conditions. This study screened out the best cultivars for Faisalabad region.

\section{Author's Contribution}

Muhammad Umer Chattha and Imran Khan: Conceived and designed the experiment.

Muhammad Dawood: Performed the experiment and collected data.

Muhammad Umer Chattha, Muhammad Dawood and Muhammad Umair Hassan: Wrote original draft.

Naeem Sarwar, Imran Khan, Muhammad Bilal Chattha, Fiaz Hussain, Muhammad Mahmood Iqbal, Muhammad Akram, Hammad Hussnain, Muhammad Shahid and Mussarrat Hussain: Reviewed and edited.

\section{Conflict of interest}

The authors have declared no conflict of interest.

\section{References}

Ali, N., Hussain, I., Ali, S., Khan, N.U. and Hussain, I., 2021. Multivariate analysis for various quantitative traits in wheat advanced lines. Saudi Journal of Biological Sciences, 28(1): 347-352. https://doi.org/10.1016/j.sjbs.2020.10.011

AOAC, 1990. Official methods of analysis, $15^{\text {th }} \mathrm{ed}$. (1990). Association of Official Analytical Chemists, Virginia, USA. 4: 69-83.

Ayaz, K., 2016. Performance of different bread wheat varieties for yield and yield attributes under diallel combinations. Annals of Agrarian Science, 14: 25-34. https://doi.org/10.1016/j. aasci.2016.03.001

Bhutta, S.K., Bhutta, K.N., Aslam, M.N., Nasir, I.R. and Ali, M.A., 2019. Evaluation of growth and yield attributes of Some Wheat
Varieties under Local Conditions of Southern Punjab, Pakistan. Journal of Plant Breeding and Genetics, 7(1): 19-25. https://doi.org/10.33687/ pbg.007.01.2865

Bonjean, A.P. and Angus, W.J., 2001. The World Wheat Book: A history of wheat breeding. Lavoisier Publication, Paris. pp. 1131.

Chattha, M.U., Hassan, M.U., Khan, I., Chattha, M.B., Mahmood, A., Nawaz, M., Subhani, M.N., Kharal, M. and Khan, S., 2017a. Biofortification of wheat cultivars to combat zinc deficiency. Frontiers in Plant Science, 8: 281. https://doi.org/10.3389/fpls.2017.00281

Chattha, M.U., Chattha, M.B., Khan, I., Anwar, U., Hassan, M.U., Nawaz, M., Anjum, S.A., Mahmood A. and Mirza, S., 2017b. Effect of seeding rate and seed soaking duration on productivity of relay-intercropped wheat in cotton. Pakistan Journal of Science, 69: 190-194.

Chattha, M.U., Khan, I., Hassan, M.U., Nawaz, M., Chattha, M.B., Ahamd, I., Khan, N.H., Usman, M., Kharal, M. and Khan, A.U., 2017c. Agronomic Appraisal of Amaranth Accessions under Semiarid Conditions of Pakistan. Pakistan Journal of Life and Social Sciences, 15(3): 144-149.

Chapman,H.D. and Parker,F., 1961.Determination of NPK. Method of analysis for soil, plant and water. Div. Agric Univ. California, USA. pp. 150-179.

Delibaltova, V. and Kirchev, H., 2010. Grain yield and quality of bread wheat varieties under the agro-ecological conditions of Dobroudja region. Bulgarian Journal of Agriculture Science, 16: $17-21$.

Government of Pakistan (GoP). Economic Survey of Pakistan. 2020. Ministry of Food, Agriculture and Livestock, Islamabad, pp. 1-25.

Hassan, M.U., Chattha, M.U., Mahmood, A. and Sahi, S.T., 2018. Performance of sorghum cultivars for biomass quality and biomethane yield grown in semi-arid area of Pakistan. Environmental Science and Pollution Research, 25(13): 12800-12807. https://doi. org/10.1007/s11356-018-1575-4

Hassan, M.U., Chattha, M.U., Ullah, A., Khan, I., Qadeer, A., Aamer, M., Khan, A.U., Nadeem, F. and Khan, T.A., 2019a. Agronomic biofortification to improve productivity and grain $\mathrm{Zn}$ concentration of bread wheat. International Journal of Agriculture and 
Biology, 21: 615-620.

Hassan, M.U., Chattha, M.U., Khan, I., Chattha, M.B., Aamer, M., Nawaz, M., Ali, A., Khan, M.A.U. and Khan, T.A., 2019b. Nickel toxicity in plants: Reasons, toxic effects, tolerance mechanisms, and remediation possibilities: A review. Environmental Science and Pollution Research, 26(13): 12673-12688. https://doi. org/10.1007/s11356-019-04892-x

Hassan, M.U., Chattha, M.U., Barbanti, L., Chattha, M.B., Mahmood, A., Khan, I. and Nawaz, M., 2019c. Combined cultivar and harvest time to enhance biomass and methane yield in sorghum under warm dry conditions in Pakistan. Industrial Crops and Products, 132: 84-91. https://doi.org/10.1016/j. indcrop.2019.02.019

Hassan, H.M., Aamer, M., Umer Chattha, M., Haiying, T., Shahzad, B., Barbanti, L., Nawaz, M., Rasheed, A., Afzal, A., Liu, Y. and Guoqin, H., 2020a. The critical role of zinc in plants facing the drought stress. Agriculture, 10(9): 396. https://doi.org/10.3390/agriculture10090396

Hassan, M.U., Chattha, M.U., Khan, I., Chattha, M.B., Barbanti, L., Aamer, M., Iqbal, M.M., Nawaz, M., Mahmood, A., Ali, A. and Aslam, M.T., 2020b. Heat stress in cultivated plants: Nature, impact, mechanisms, and mitigation strategies: A review. Plant Biosystems, 155: 211234. https://doi.org/10.1080/11263504.2020.1 727987

Hassan, M.U., Chattha, M.U., Barbanti, L., Mahmood, A., Chattha, M.B., Khan, I., Mirza, S., Aziz, S.A., Nawaz, M. and Aamer, M., 2020c. Cultivar and seeding time role in sorghum to optimize biomass and methane yield under warm dry climate. Industrial Crops and Products, 145: 111983. https://doi. org/10.1016/j.indcrop.2019.111983

Hassan, M.U., Aamer, M., Nawaz, M., Rehman, A., Aslam, T., Afzal, U., Shahzad, B.A., Ayub, M.A., Ahmed, F., Qiaoying, M. and Qitao, S., 2021. Agronomic bio-fortification of wheat to combat zinc deficiency in developing countries. Pakistan Journal of Agricultural Research, 34(1): 201-2017. https://doi. org/10.17582/journal.pjar/2021/34.1.201.217

Hussain, I., Khan, M.A. and Khan, E.A., 2006. Bread wheat varieties as influenced by different nitrogen levels. Journal of Zhejiang University of Science, 7(1): 70-78. https://doi.org/10.1631/
jzus.2006.B0070

Iqbal, M., Khan, M.A. and Anwar, M.Z., 2002. Zero-tillage technology and farm profits: $A$ case study of wheat growers in the rice zone of Punjab. The Pakistan Development Review, 41: 665-682. https://doi.org/10.30541/ v41i4IIpp.665-682

Iqbal, Z., Pasha, I., Abrar, M., Masih, S. and Hanif, M.S., 2015. Physico-chemical, functional and rheological properties of wheat varieties. Journal of Agriculture Research, 53(2): 253-266.

Inamullah, H. Ahmad, F., Sirajuddin, M., Hassan, G., Gul, R., 2006. Diallel analysis of the inheritance pattern of agronomic traits of bread wheat. Pakistan Journal of Botany, 38(4): 11691175.

Ilyas, M., Khan, I., Chattha, M.U., Hassan, M.U., Zain,M.,Farhad,W.,Ullah,S.,Shah,A.,Ahmed, S., Khan, B. and Adeel, M., 2020. Evaluating the effect of zinc application methods on growth and yield of wheat cultivars. Journal of Innovative Sciences, 6(2): 150-156. https://doi. org/10.17582/journal.jis/2020/6.2.150.156

Jamal, K., Bari, I.H., Khan, S. and Zada, I., 2009. Genetic variation for yield and yield components in rice. ARPN Journal of Agriculture and Biological Science, 46: 60-64.

Kahrizi, D., Cheghamirza, K., Kakeai, M., MohammadiR.andEbadi,A.,2010.Heritability and genetic gain of some morphophysiological variables of durum wheat (Triticum turgidum var. durum). African Journal of Biotechnology, 9(30): 4687-469.

Kiliç, H. and Gürsoy, S., 2010. Effect of seeding rate on yield and yield components of durum wheat cultivars in cotton-wheat cropping system. Scientific Research and Essays, 5: 2078-84.

Malik, A.U., Haji, M.A., Bukhsh, A., Hussain, I., Athar, M. and Ali, M., 2009. Comparative performance of some new wheat cultivars in agro-ecological zone of DG Khan. Journal of Agriculture and Plant Sciences, 19: 78-81.

Mary, S.S. and Gopalan, A., 2006. Dissection of genetic attributes yield traits of fodder cowpea in F3and F4. Journal of Applied Science Research, 2(10):805-808.

Migliorini, P., Spagnolo, S., Torri, L., Arnoulet, M., Lazzerini, G. and Ceccarelli, S., 2016. Agronomic and quality characteristics of old, modern and mixture wheat varieties and landraces for organic bread chain in diverse 
environments of northern Italy. European Journal of Agronomy, 79: 131-141. https://doi. org/10.1016/j.eja.2016.05.011

Muhsin, M., Nawaz, M., Khan, I., Chattha, M.B., Khan, S., Aslam, M.T., Iqbal, M.M., Amin, M.Z, Ayub, M.A., Anwar, U., Hassan, M.U. and Chattha, M.U., 2021. Efficacy of seed size to improve field performance of wheat under late sowing conditions. Pakistan Journal of Agricultural Research, 34(1): 247253. https://doi.org/10.17582/journal. pjar/2021/34.1.247.253

Mushtaq, T.,Hussain, S., Bukhsh, M., Iqbal, J. and Khaliq, T., 2011. Evaluation of two wheat genotypes Performance of under drought conditions at different growth stages. Crop and Environment, 2: 20-27.

Nasim, W., Ahmed, A., Tariq, M. and Wajid, S.A., 2012. Studying the comparative performance of wheat cultivars for growth and grains production. International Journal of Plant Production, 3: 306-312.

Naveed, K., Khan, M.A., Baloch, M.S., Ali, K., Nadim, M.A., Khan, E.A., Shah, S. and Arif, M., 2014. Effect of different seeding rates on yield attributes of dual-purpose wheat. Sarbad Journal of Agriculture, 30: 83-91.

Ofversten, J., Jauhiainen L., Nikander, H. and Salo, Y., 2002. Assessing and predicting the local performance of spring wheat varieties. Journal of Agriculture Science, 139(4): 397-404. https://
doi.org/10.1017/S0021859602002642

Olsen, R., Cole, C.V., Watanabe, F.S. and Dean, L.A., 1954. Estimation of available phosphorus in soils by extraction with sodium bicarbonate. Circular 939. Washington (DC): United States Department of Agriculture.

Razzaq, A., Ali, Q., Qayyum, A., Mahmood, A., Ahmad,M. and Rashid, M., 2013. Physiological responses and drought resistance index of nine wheat (Triticum aestivum L.) cultivars under different moisture conditions. Pakistan Journal of Botany, 45: 151-155.

Saleem, U., Khaliq, I., Mahmood, T. and Rafique, M., 2006. Phenotypic and genotypic correlation coefficients between yield and yield components in wheat. Journal of Agriculture Research, 44(1): 1-8.

Shafi, M., Khan, M.J., Bakht, J. and Khan, M.A., 2013. Response of wheat genotypes to salinity under field environment. Pakistan Journal of Botony, 45(3): 787-794.

Steel, R.G.D., Torrie, J.H., Dickey, D., 1997. Principles and Procedures of statistics: A biometric approach. 3rd edition, McGraw-Hill Book Co., New York, USA pp. 663-666.

Zain, M., Khan, I., Chattha, M.U., Qadri, RWK, Anjum, S.A., Hassan, M.U., Mahmood, A. and Ilyas, M., 2017. Foliar applied thiourea at different growth stages modulated late sown wheat. Pakistan Journal of Science, 69(1): 39-43. 